DOI: $10.34305 /$ gemic.v1i1.321

\title{
THE EFFECT OF PROVIDING EDUCATION USING ONLINE MEDIA FOR PREGNANT WOMEN ON MOTHER'S KNOWLEDGE, SUCCESS OF BREASTFEEDING ONLY FOR ONE MONTH AND MOTHER'S SELF EFFICACY
}

\author{
Ririn Riyadussolihat, Neli Nurlina \\ Poltekkes Kemenkes Tasikmalaya \\ r2ririnrs@gmail.com
}

\begin{abstract}
Introduction: Breastmilk is the first food for newborns and is the main nutrition for babies. The low level of exclusive breastfeeding is due to the lack of knowledge of mothers about exclusive breastfeeding. Therefore, in order for mother's knowledge to be good, it can be done by providing education about exclusive breastfeeding. The purpose of this study was to determine the effect of providing education using online media for pregnant women on the knowledge of mothers in breastfeeding, self-efficacy and the success of breastfeeding alone for one month. Methods: This study used a quasi-experimental design with a pre and post-test nonequivalent control group approach. The sampling technique used probability sampling, which consisted of 44 pregnant women in the third trimester. Collection using a questionnaire and analyzed using the chi square test with a significance level of $\alpha \leq 0.05$. Results: This study shows that there is no significant relationship between the provision of online education and maternal knowledge with a p value of $0.056(\alpha \geq 0.05)$. There is a significant relationship between providing online education with maternal self-efficacy with a $p$ value of $0.001(\alpha \leq$ 0.05). There was no significant relationship between the provision of education and the success of breastfeeding for 1 month with a p value of $0.186(\alpha \geq 0.05)$. Conclusion: It is suggested that health walkers can increase educational activities regarding exclusive breastfeeding by using any method and in an appropriate, structured and continuous way with direct or indirect interactions so that the knowledge and self-efficacy of mothers about exclusive breastfeeding will be better.
\end{abstract}

Keywords: education; online; knowledge; self efficacy; breastfeeding success. 


\section{Introduction}

According to WHO (2018),

Sarinengsih (2020) citation, the impact that occurs if babies are not given exclusive breastfeeding, namely, can increase infant mortality 3-4 times greater than babies who are given exclusive breastfeeding, low all intellectual functions including verbal abilities and visual motor skills of babies, babies will be susceptible to various kinds of infectious diseases and cause stunting (Qoyyimah and Rohmawati, 2017).

In Indonesia, $29.5 \%$ of babies who have been exclusively breastfed until the age of six months (Kemenkes RI, 2017). This is not in accordance with the Ministry of Health's Strategic Plan target for 20152019, namely the percentage of 6 month babies who receive exclusive breastfeeding is $50 \%$ (Istianingsih, 2018).

The low level of exclusive breastfeeding is due to the lack of knowledge of mothers and family support. Therefore, so that mothers have good knowledge, it can be done by providing education about exclusive breastfeeding to the parents of the baby, not only to the mother but also to the father involved. Because the process of breastfeeding does not only involve mothers and babies (Amalia, 2017).
Education about exclusive breastfeeding should be able to increase knowledge, because health education aims to increase knowledge and ability in breastfeeding. Besides that, it also affects a positive attitude in breastfeeding. This is evidenced research by Merdhika, Mardji and Devi (2014) with a $\mathrm{p}$ value of 0.000 . Supported research by Suhertusi, Desmiwarti and Nurjasmi (2015) with a p value of 0.001 . From these two studies, it shows that there is an effect of counseling on increasing the knowledge of mothers in exclusive breastfeeding.

Besides influencing knowledge, education also affects the success of exclusive breastfeeding. This is supported research by Rosidi (2017) which is marked with a $\mathrm{p}$ value of 0.036 . The results of this study indicate an effect of lactation counselor education on breastfeeding success. Another study conducted by Risnaningsih (2012) showed that there was an effect of nurse education on late trimester primigravida mothers on the success of first week breastfeeding at PKU Muhammadiyah Bantul Hospital in 2012 with a $p$ value of 0.024 .

Education also affects the mother's self-efficacy in exclusive breastfeeding. According to Riyanti, Nurlaila and 
Astutiningrum (2018) Self-efficacy will provide positive values for mothers in breastfeeding, the breastfeeding process, the success of breastfeeding, and bounding between mother and baby. From this impact, self-efficacy has a positive value for breastfeeding mothers. It is also supported by research conducted by Martika, Wahyuntari and Utami (2019) which shows the influence of breastfeeding education on the self-efficacy of mothers to breastfeed babies at PKU Muhammadiyah Yogyakarta Hospital with a p value of 0.04.

Education will be effective if it uses the right media and methods. Many previous studies have examined the use of educational media to increase knowledge, the success of exclusive breastfeeding and maternal self-efficacy. The media used were leaflets, powerpoints, booklets, videos. This is evidenced by the results of research by Afriyani and Salafas (2019) which are marked with a $\mathrm{p}$ value of 0.002 . With the results there is an increase in knowledge after treatment, indicated by differences in knowledge before and after health promotion with leaflet media. Likewise, the research of Ismawati and Abdulrahman (2017) shows that there is an effect of using leaflet media on the level of knowledge of postpartum mothers about infant breastfeeding techniques with a $\mathrm{p}$ value of 0.000. Similar to Safitri (2018) research, with the results of the effect of providing booklets on increasing husband's knowledge, attitudes, and support for exclusive breastfeeding in third trimester pregnant women with a $\mathrm{p}$ value of 0.018 .

\section{Method}

This research is a quantitative study using a quasi-experimental design or quasiexperimental research with a pre and posttest nonequivalent control group approach. Quasi experiment is a research method that aims to try out intervention or treatment in a group without comparisons and randomization (random allocation) with a control or comparison group. The pre and post-test nonequivalent control group is a quasi-experimental research design in which the implementation of the study divides respondents into two or more groups, namely the treatment and control groups (Dharma, 2017).

In the research design, the intervention and control groups were given pretest before the treatment was carried out, aiming to assess the knowledge of mothers in breastfeeding and the success of breastfeeding alone for one month, after being given the intervention in the 
treatment and control groups, an assessment of the results was carried out through posttest. The interventions carried out in this study were providing education about exclusive breastfeeding online (via the WhatsApp application) to the treatment group (intervention) and giving leaflets through the WhatsApp application to the control group.

The sampling technique used in this research is probability sampling, namely simple random sampling. How to collect it using lottery numbers. To determine the minimum sample size, it can be calculated using the Lemeshow et al., (1997). Based on the sample size formula, the minimum sample for each group is 20 people. If there is a sample drop out, then the sample correction for each group is $10 \%$, so the number of samples is 22 for each group.

Online education is provided using the Whatsapp application in the form of video calls and voice calls. In the intervention group and the control group, the WA group was made, the intervention group was carried out 3 times with a break of 4 days and 1 evaluation at term mothers for 1 month, in providing education, it must pay attention to delivery time and activity level so that education can be conveyed and understood by respondents. At the first meeting discussing what exclusive breastfeeding is and the benefits of exclusive breastfeeding, at the second meeting discussed the impact and management of lack of breastfeeding in infants and problems in breastfeeding or breastfeeding such as blistered nipples, breast milk does not come out and insufficient breast milk so that the mother switches. to formula milk. The third meeting before the evaluation conveyed about the position and attachment of breastfeeding in the form of a video, the last was an evaluation of whether the mother gave breast milk only to her baby for 1 month.

This research was conducted by creating 2 separate WhatsApp groups between the intervention group and the control group. In the intervention group, education was provided through messages and group voice calls were carried out every 5 respondents out of 22 respondents. In the control group, leaflets were given after the pretest through the WhatsApp application and leaflets containing an explanation of exclusive breastfeeding, the benefits or benefits and impacts of not being breastfed if the baby was given breastfeeding, also accompanied by a picture of the good and correct latch 
position Data collection in the intervention group was carried out every day and carried out pretest and posttest, while in the control group, leaflets were given only once and carried out pretest and posttest, after obtaining permission from the Tirtamulya Health Center.

Data collection tools used in this study were research instruments in the form of questionnaires and observation sheets. The questionnaire contains a spreadsheet related to the dependent variable, namely the knowledge of mothers in breastfeeding and the success of breastfeeding alone for one month and the mother's self-efficacy.
The questionnaire contains variables of mother's knowledge in breastfeeding, which were given before and after the intervention was given to education through online media to mothers in the intervention group, and after giving leaflets to the control group. Distribution of questionnaires through online media using google form.

Univariate analysis was carried out by analyzing the frequency distribution and percentage of variables. This type of bivariate analysis is used to see the relationship between two variables by using the Chi Square test analysis.

\section{Results}

Table 1. The Relationship Between Education Using Online Media With Mother's Knowledge at Tirtamulya Public Health Center, Karawang Regency in 2020

\begin{tabular}{ccccccccc} 
& \multicolumn{4}{c}{ Knowledge } & \multicolumn{2}{c}{ Total } & \multirow{2}{*}{ P value } & CI \\
\cline { 2 - 6 } Group & \multicolumn{2}{c}{ Good } & \multicolumn{2}{c}{ Less } & & & 95\% \\
\cline { 2 - 7 } & F & \% & F & \% & F & \% & & \\
\hline Control & 11 & 37,9 & 11 & 73,3 & 22 & 100 & \multirow{2}{*}{0,056} & $1,14-$ \\
Intervention & 18 & 62,1 & 4 & 26,7 & 22 & 100 & & 17,67 \\
\hline
\end{tabular}

Based on Table 1, it shows that there is no significant relationship between the provision of online education and the knowledge of mothers about exclusive breastfeeding which is marked with a $\mathrm{p}$ value of $0.056(\alpha \geq 0.05)$. These statistical results not only apply to the sample but also apply to populations marked with a CI not exceeding 1 , where the $\mathrm{CI}$ is in the range $1.14-17.67$.

Table 2. The relationship between education using online media and breastfeeding success at Tirtamulya Public Health Center, Karawang Regency, 2020

$$
\text { Group Success of Breastfeeding Total Pvalue } 95 \% \mathrm{CI}
$$




\begin{tabular}{ccccccccc} 
& \multicolumn{9}{c}{ Yes } & \multicolumn{1}{c}{ No } & & \\
\cline { 2 - 7 } & F & \% & F & \% & F & \% & & \\
\hline Control & 13 & 41,9 & 9 & 69,2 & 22 & 100 & 0,186 & $0,78-$ \\
Intervention & 18 & 58,1 & 4 & 30,8 & 22 & 100 & & 12,34 \\
\hline
\end{tabular}

Based on Table 2, it shows that there is no significant relationship between providing online education with the success of one month breastfeeding marked with a $p$ value of $0.186(\alpha \geq 0.05)$. These statistical results only apply to the study sample and do not apply to populations marked with a CI exceeding 1, where the $\mathrm{CI}$ is in the range $0.78-12.34$.

Table 3. The Relationship Between Education Using Online Media With Self Efficacy at Tirtamulya Health Center, Karawang Regency, 2020

\begin{tabular}{|c|c|c|c|c|c|c|c|c|}
\hline \multirow{3}{*}{ Group } & \multicolumn{4}{|c|}{ Self Efficacy } & \multirow{2}{*}{\multicolumn{2}{|c|}{ Total }} & \multirow{3}{*}{ P value } & \multirow{3}{*}{$95 \% \mathrm{CI}$} \\
\hline & \multicolumn{2}{|c|}{ Good } & \multicolumn{2}{|c|}{ Less } & & & & \\
\hline & $\mathbf{F}$ & $\%$ & $\mathbf{F}$ & $\%$ & $\mathbf{F}$ & $\%$ & & \\
\hline Control & 9 & 31,0 & 13 & 86,7 & 22 & 100 & 0,001 & $2,68-$ \\
\hline Intervention & 20 & 69,0 & 2 & 13,3 & 22 & 100 & 0,001 & 77,79 \\
\hline
\end{tabular}

Based on Table 3, it shows that there is a significant relationship between providing online education with maternal self-efficacy in exclusive breastfeeding marked with a $p$ value of $0.001(\alpha \leq 0.05)$.

\section{Discussion}

The results of the study statistically using the chi square test showed $\mathrm{p}$ value $=$ $0.056(\alpha \geq 0.05)$. This shows that there is no significant relationship between providing online education with maternal knowledge. These statistical results not only apply to the sample but also apply to populations marked with a CI not exceeding 1 , where the $\mathrm{CI}$ is in the range $1.14-17.67$. The
These statistical results not only apply to the sample but also apply to populations marked with a CI not exceeding 1, where the $\mathrm{CI}$ is in the range $2.68-77.79$.

results of this study are not in line with the research of Amalia, Nugrahaeni and Kartini (2018) which states that there is a relationship between the provision of nutritional education to the knowledge of prospective mothers in preventing chronic energy deficiency in pregnant women which is marked with a $p$ value of $0.001(\alpha$ $\leq 0.05)$.

Based on the results of research and existing theories, the researchers can 
conclude that education given using any method, either online or leaflets or directly or indirectly, will increase the mother's knowledge as long as it is given education in the right way and method.

The results of the study statistically using the chi square test showed $\mathrm{p}$ value $=$ $0.186(\alpha \geq 0.05)$. This shows that there is no significant relationship between providing online education with the success of breastfeeding. These statistical results only apply to samples and do not apply to populations marked with a CI exceeding 1 , where the $\mathrm{CI}$ is in the range $0.78-12.34$. The results of this study are not in line with the research of Risnaningsih (2012) which states that there is a relationship providing nurse education to late trimeser primigravida pregnant women to the success of first week breastfeeding at PKU Muhammadiyah Bantul Hospital with a $p$ value of $0.024(\alpha \leq 0.05)$ with a CI limit of 0.028. - 0.997.

The results of this study indicate that there is no relationship with the success of breastfeeding. The results of this study only apply to 44 respondents but do not apply to the population of 396 pregnant women. The reason online education is not related to the success of breastfeeding is because the selection of respondents is not homogeneous. Respondents have different parities, namely primiparous and multiparous. This can lead to the success of exclusive breastfeeding not only by providing education alone, but positive or negative breastfeeding experiences can also affect it.

Based on the results and existing theories, the researcher can conclude that education can increase the success of exclusive breastfeeding as long as the education is given with the right method, time and way. In addition, education must be carried out continuously with assistance by health workers so that mothers have a pleasant and positive experience during breastfeeding so that they have the opportunity to provide exclusive breastfeeding to the next child.

The results of the study statistically using the chi square test showed $\mathrm{p}$ value $=$ $0.001(\alpha \leq 0.05)$. This shows that there is a significant relationship between providing online education with maternal self-efficacy in breastfeeding. These statistical results not only apply to the sample but also apply to populations marked with the CI not exceeding 1 , where the $\mathrm{CI}$ is in the range $2.68-77.79$. This is in line with the results of Martika, Wahyuntari and Utami (2019) research which states that there is an effect 
of breastfeeding education on mothers' selfefficacy for breastfeeding babies with a $p$ value of $0.04(\alpha \leq 0.05)$.

Self-confidence will increase if there is contact or interaction between health workers and pregnant women and when there is support or support. This is evidenced by the research of Bonsaksen, Lerdar and Fagermoen (2012) which states that external factors that can increase a person's self-efficacy are the presence of interaction and a good support system.

Based on the results of research and existing theories, the researcher can conclude that education will increase a person's self-efficacy if education is carried out in a structured manner and there is direct contact or interaction between health workers and mothers.

\section{Conclusion}

Before giving education, the majority of the 44 respondents had less knowledge and self-efficacy, but after the provision of education, the majority of knowledge and self-efficacy were good. As for the success of breastfeeding for 1 month, it shows that of the 44 respondents the majority gave exclusive breastfeeding for 1 month.
There is no significant relationship between providing online education to maternal knowledge about exclusive breastfeeding, as well as the success of breastfeeding for 1 month. However, the results differ on self-efficacy, where there is a significant relationship between providing online education to maternal self-efficacy in breastfeeding.

\section{Suggestion}

1. For health walkers

It is hoped that it can increase the activities of providing education or health education regarding exclusive breastfeeding. This can be done using any method and in an appropriate, structured and continuous way with direct or indirect interactions so that the knowledge and self-efficacy of mothers about exclusive breastfeeding are better.

2. For further researchers

It is expected to consider the selection of respondents who are homogeneous or have the same characteristics. In addition, it considers the larger number of respondents and uses different methods and analyzes. 


\section{Reference}

Afriyani, L. D. and Salafas, E. (2019) 'Efektifitas Media Promosi Kesehatan ASI Perah Terhadap Peningkatan Pengetahuan Ibu Bekerja Untuk Memberikan ASI Eksklusif', Jurnal SIKLUS, 8(1), pp. 60-66.

Amalia, F., Nugrahaeni, S. A. and Kartini, A. (2018) 'Pengaruh Edukasi Gizi Terhadap Pengetahuan Dan Praktik Calon Ibu dalam Pencegahan Kurang Energi Kronik Ibu Hamil', Jurnal Kesehatan Masyarakat, 6(5), pp. 370377.

Amalia, S. (2017) 'Orang Tua Bekerja pun Bisa Sukses Memberi ASI Eksklusif’, Asosiasi Ibu Menyusui Indonesia.

Bonsaksen, T., Lerdar, A. and Fagermoen, M. A. Y. S. (2012) 'Factors associated with self-efficacy in persons with chronic illness Study design', Scandinavian Journal of Psychology, pp. 333-339.

Dharma, K. (2017) Metodologi penelitian keperawatan: Panduan melaksanakan dan menerapkan hasil penelitian (Revisi). Jakarta: Trans Info Media.

Ismawati and Abdulrahman, N. K. (2017) 'Pengaruh Penggunaaan Media Leaflet Terhadap Tingkat Pengetahuan Ibu Nifas Tentang Tenik Menyusui Bayi Di Puskesmas Mamajang Makassar', Jurnal Ilmiah Media Bidan, 2(2).

Istianingsih, A. (2018) 'Hubungan Breastfeeding Self-Efficacy dengan Pemberian ASI Eksklusif di Wilayah Puskesmas Air Dingin Kota Padang Tahun 2018', Diploma Thesis, Universitas Andalas, pp. 1-7.
Kemenkes RI (2017) Profil Kesehatan Indonesia Tahun 2017.

Lemeshow, S. et al. (1997) Besar Sampel dalam Penelitian Kesehatan. Pertama. Edited by D. Pramono. Yogyakarta: Fakultas Kedokteran Universitas Gadjah Mada.

Martika, A., Wahyuntari, E. and Utami, I. (2019) 'Pengaruh Edukasi Pemberian Air Susu Ibu ( ASI ) Terhadap Self Efficacy Ibu Untuk Menyusui Bayi Di RS PKU Muhammadiyah Yogyakarta Tahun 2019', Universitas 'Aisyiyah Yogyakarta.

Merdhika, W. A. R., Mardji and Devi, M. (2014) 'Pengaruh penyuluhan asi eksklusif terhadap pengetahuan ibu tentang asi eksklusif dan sikap ibu menyusui di kecamatan kanigoro kabupaten blitar', Teknologi Dan Kejuruan, 37(1), pp. 65-72.

Qoyyimah, A. U. and Rohmawati, W. (2017) 'Dampak Pemberian ASI Eksklusif Terhadap Kejadian Sakit Pada Bayi 6-12 Bulan Di Kabupaten Klaten', Universitas Ahmad Dahlan Yogyakarta.

Risnaningsih, S. Y. (2012) Pengaruh Edukasi Perawat Pada Ibu Primigravida Trimester Akhir Terhadap Keberhasilan Pemberian ASI Minggu Pertama Di RS PKU Muhammadiyah Bantul, STIKES 'Aisyiyah Yogyakarta.

Riyanti, E., Nurlaila and Astutiningrum, D. (2018) 'Pengaruh edukasi breastfeeding ibu post partum terhadap breasfeeding self efficacy', Jurnal Ilmiah Kesehatan Keperawatan, 14(3). 
Rosidi, I. Y. D. (2017) 'Pengaruh Edukasi Konselor Laktasi Terhadap Keberhasilan Menyusui 3 Bulan Pertama Di Puskesmas Bontomarannu', Jurnal Kebidanan Vokasional, pp. 83-88.

Safitri, D. F. (2018) Pengaruh Pemberian Booklet Terhadap Peningkatan Pengetahuan, Sikap, Dan Dukungan Suami Terhadap ASI Eksklusif Pada Ibu Hamil Di Puskesmas Ngampilan Dan Puskesmas Wirobrajan, Poltekkes Kemenkes Yogyakarta. doi: 10.1017/CBO9781107415324.004.

Sarinengsih, Y. (2020) 'Hubungan Pemberian Asi Eksklusif Dengan
Kejadian Stunting Pada Balita Usia 1-5 Tahun Dipuskesmas Sukahening Kecamatan Sukahening Kabupaten Tasikmalaya', Jurnal Ilmu Kesehatan Immanuel, 13(2), p. 109 . doi: 10.36051/jiki.v13i2.102.

Suhertusi, B., Desmiwarti and Nurjasmi, E. (2015) 'Pengaruh Media Promosi Kesehatan tentang ASI Eksklusif terhadap Peningkatan Pengetahuan Ibu di Wilayah Kerja Puskesmas Lubuk Begalung Padang Tahun 2014', Jurnal Kesehatan Andalas, 4(1), pp. 17-22. 